\title{
Belgeo
}

Revue belge de géographie

$4 \mid 2018$

Transformations of urban space after the fall of Socialism

\section{Budapest's fragmented riverfront renewal: Western trends interspersed with post-socialist characteristics}

Le renouvellement riverain fragmenté de Budapest: Tendances occidentales

émaillées de caractéristiques post-socialistes

\section{Gabor Tolnai}

\section{(2) OpenEdition}

\section{Journals}

Electronic version

URL: http://journals.openedition.org/belgeo/21210

DOI: $10.4000 /$ belgeo.21210

ISSN: 2294-9135

\section{Publisher:}

National Committee of Geography of Belgium, Société Royale Belge de Géographie

\section{Electronic reference}

Gabor Tolnai, «Budapest's fragmented riverfront renewal: Western trends interspersed with postsocialist characteristics », Belgeo [Online], 4 | 2018, Online since 31 May 2018, connection on 09 October 2020. URL : http://journals.openedition.org/belgeo/21210; DOI : https://doi.org/10.4000/ belgeo. 21210

This text was automatically generated on 9 October 2020 .

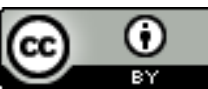

Belgeo est mis à disposition selon les termes de la licence Creative Commons Attribution 4.0 International. 


\title{
Budapest's fragmented riverfront renewal: Western trends interspersed with post-socialist characteristics
}

\author{
Le renouvellement riverain fragmenté de Budapest: Tendances occidentales \\ émaillées de caractéristiques post-socialistes
}

Gabor Tolnai

\section{The appearance and spread of the 'waterfront' phenomenon}

'Waterfront', in a broader understanding, is 'a space where water (i.e., river, lake, sea and ocean) meets with urbanized land, creating a unique spatial interface' (Davidson, 2009, p. 12:215). The literature on this topic, however, takes a narrower focus: it concentrates on the disappearance of industrial and transport zones from the water's edge and on the new forms of land use, as well as on the practices of renewal. Scholars have employed complex approaches to this field, as the functional change of waterfronts has numerous social and economic effects, which also impact other parts of the city. The rehabilitation of these zones is not a new phenomenon, nor are the conflicts generated by the opposing interests of different actors (Desfor et al., 2011). In most instances, the utilization of water's edge had been strongly connected to the inner-city (e.g. historical ports) but with their industrialization, these zones became aesthetically problematic, separating the inner-city from the water. 'Most industrial cities', as Shaw (2001, p. 160) has put it, 'had turned their backs on their waterfronts'.

2 The problems stemming from the decline of ports and the connected industrial zones became evident in the North Atlantic region throughout the 1960s and '70s. In addition to the decline of fordist production, the transformation of shipping was the other main 
cause behind the downfall of harbors. Traditional port activities were replaced by more efficient and economical forms of automatized containerization, and since traditional port-towns could not receive larger ships, the ports themselves moved seawards (Hoyle, 1988). Therefore, the unused former ports of inner-cities required new functions in the urban landscape. The redevelopment of these zones started in North American cities, and then spread across the world in the following decades. According to the model of global diffusion (Hoyle, 2000), the transformation of port-towns is interpreted as a continuous expansion, having started from the Eastern Coast of the US, proceeding to semi-peripheral and peripheral countries through the large cities of the core countries.

3 Shaw (2001) considers this global transformation as a step-by-step process, and identifies four generations of waterfront development. By and large, the first generation consists of coastal US cities. In this initial phase, centrally organized, project-led, spotlight interventions were typical (Cook et al., 2001). During the second wave, waterfront regeneration was characteristically controlled by specialized urban development corporations. Other metropolises of economically developed Anglo-Saxon countries joined the process in the 1970s and 80s, then the early birds of Western Europe in the late 1980s. The extent of the interventions reached the scale of entire neighbourhoods, and they were often connected to mega-projects (e.g. expos, sport events). However, as urban development corporations gained firm hold over the projects, the interests of private investors were over-represented in the decision making process. The former (mostly working-class) inhabitants of the sites were often forced to move away. Consequently, these changing neighbourhoods experienced remarkable gentrification. Whereas the position and competitiveness of these cities significantly improved (owing to the regeneration of their waterfronts), social and economic polarization has increased locally (Brownill, 2011). In response, critical assessment of waterfront regeneration was first carried out in the cities of the third generation. Here, several measures were taken to suppress the predominance of private capital. Cooperation between local governments, residents and entrepreneurs became more important, in line with the harmonization of development on regional and local scales (Vegara, 2001). Several European cities realized successful regeneration by following the principle of public-private partnerships (PPPs). In other instances, however, the mimicry of second generation projects - without evaluating them in the local context - led to unsuccessful outcomes, especially in the cities of recently industrialized regions (e.g. Mountjoy, 2013). In the fourth wave, the ideals of sustainability and liveability have become preferred to megaprojects, predominantly since the turn of the millennia. Mixed use of waterfronts has gained popularity. Nevertheless, the active support of the public sector is still needed. 'Waterfront' is a key element of city-marketing today: 'the waterfront became the particular place where the transformation from the fordist industrial city to the post-industrial and science-based city could be accomplished - that is, the place where a shift 'from ships to chips' could occur' (Schubert, 2011, p. 93). During this last period, not only the coastal and riverfront cities of peripheral countries have joined the global diffusion of waterfront regeneration, but the medium- and small sized towns of core countries as well. Thus, the expansion presented by Hoyle (2000) might be supplemented by a local component: the phenomenon spreads downwards in the urban hierarchy.

Urban studies have become involved in studying waterfronts since the late ' 80 s, and this body of literature has broadened gradually. Based on the results of pathbreaking 
studies (e.g. Hoyle et al., 1988; Bruttomesso, 1993; Hoyle, 1996; Malone, 1996) and edited thematic volumes (e.g. Marshall, 2001; Desfor et al., 2011), a wide range of regional (e.g. Smith and Ferrari, 2012; Carta and Ronsivalle, 2016) and local case studies have been published. As an outcome of this pluralization, recent publications vary both geographically and methodologically. Regarding the latter one, two main approaches flourish. First, the studies by social scientists mostly investigate the political, economic and social context behind the conflicts of regeneration through a critical lens. Second, the works of engineers highlight the advantages of renewal, preparing the reproduction of results achieved elsewhere (Desfor et al., 2011). In the meantime, several cities of semi-peripheral and peripheral countries also started to (re-)discover their reusable waterfronts after 2000 , and the number of publications on this topic significantly increased during the last 10 years. Coastal or riverfront cities of the postsocialist realm, among them the Hungarian capital, also belong to this group.

\section{Is Budapest a waterfront city?}

5 Although Budapest is not a typical port-town, its former role as a hub on the Danubian waterway might still justify its investigation in this context. Furthermore, since its first industrial zones (emerged in the $19^{\text {th }}$ century) were closely connected to the river, the city inherited vast brownfield areas on its riversides (Barta et al., 2006). In this sense, the Hungarian capital might be regarded as a city in the initial phase of waterfront redevelopment. In addition, the appearance of the notion of 'riverfront' ${ }^{1}$ in the related literature also gives reasons to such a research. The length of riversides within the administrative boundaries of Budapest is significant ${ }^{2}$. However, only a few (geographical) studies have dealt with the waterfronts of Budapest. The general types of land use on the city's riversides were examined by Izsák and Probáld (2008), whereas Szabó and Gordos (2015) investigated the influences of the regulatory system and the changing financial framework on the development of waterfronts in the entire city. Bodnár and Veres's (2013) case study took a more specialized approach, examining the conflicts between various actors on a rapidly developing waterfront site (the ' Millennium City Center'), while Berki (2012) surveyed the transformation of the urban fabric in the same area.

6 Nonetheless, did Budapest really become a waterfront city? The first step could have been the realization of the plans for Expo '95 Vienna-Budapest (later only Expo '96 Budapest). If it had been completed, the Hungarian capital would have joined the global process of waterfront regeneration on the turning point of the second and the third generations (as defined by Shaw, 2001) with a typical megaproject. The city would have become a Central European bridgehead of the global diffusion (Hoyle, 2000). However, the plans were not realized due to the financial crisis and political struggles of the early years of the post-socialist transition. The sites dedicated to the Expo were only cleansed, and a new bridge was built in order to explore the neighbourhood. More than 20 years later, a successful application for the Olympic Games 2024 could have also made Budapest a waterfront city. In this plan, most of the sites were riverfront brownfields. But in early 2017, the municipality withdrew its application because of a political struggle again. Nevertheless, it remains an interesting question whether Budapest could have realized the hybrid of a waterfront megaproject (typical to the 
second generation) and community-based sustainable development (specific to the fourth generation).

7 In fact, since both large-scale investments have failed, the riverfront redevelopment of Budapest is rather slow. Instead of a project encompassing the city's entire waterfront, the functional change of previously used lands takes place in smaller territories, scattered along the Danube. As most formerly industrial zones remained intact during the fall of socialism (Barta et al., 2006) the functional transformation of the valuable waterfront sites proceeded under the conditions of the post-socialist transition to capitalism. The political struggles both on the local and the national scale have left their marks on the process. In addition to the lack of transparence of privatization, little emphasis was placed on public interests. Therefore, we might only cautiously state that Budapest (as a whole) is becoming a riverfront city; it is rather realistic to identify a number of spectacularly developing riverfront zones within the city.

\section{An attempt to use Western models in the case of the waterfronts of post-socialist Budapest}

8 The models ${ }^{3}$ investigating the long-term relationship between cities and ports in the Western context describe a period of growth, followed by the maturity and decline of the port. The port-city interface model (Hoyle, 1988) describes a rivalry for these sites after the disappearance of their original functions. It distinguishes between 'land-use competition' and 'water-use competition', and as the needs of new functions diverge, it sets out the existence of a 'zone of conflict'4. Briefly, the model concentrates on the 'struggle' for lands on the water's edge. In contrast to that, the concept developed by Pinch and Munt (2002) is based on the interrelation between land and water. ${ }^{5}$ In their opinion, ‘ waterspace' (i.e. the working, transporting and recreational functions that actually utilize water-body) comes to the fore, replacing the 'land-based perspective' (i.e. the profit-oriented redevelopment of $2^{\text {nd }}$ generation waterfronts). Hence, the turn from " waterfront' (reusable lands on water's edge) to 'bluefield' (linking point/surface between water and land) has a symbolic meaning as well, highlighting the changing preferences of renewal.

9 According to Schubert (2011), waterfront regeneration of large Western European harbors might be divided into five steps. Although his study focuses on a delimited group of cities, his model can be broadened and used in a more general sense. (I.) The first step, i.e. the seaward movement of large harbors, might be replaced with the decline of smaller (riverside) ports and other water-based industries. The following phases are also adaptable: (II.) underused or abandoned waterfronts remain in innercities, (III.), which evokes interests in reusing, prompts plans of regeneration, (IV.) that is followed by realization, and (V.) finally, the effects of renewal changes the functions of the neighbouring parts of the city. The process generally starts at the points closest to the inner-city or a historical center, and later expands to more remote zones. 
Figure 1. Redeveloped waterfronts and potential sites in Budapest.

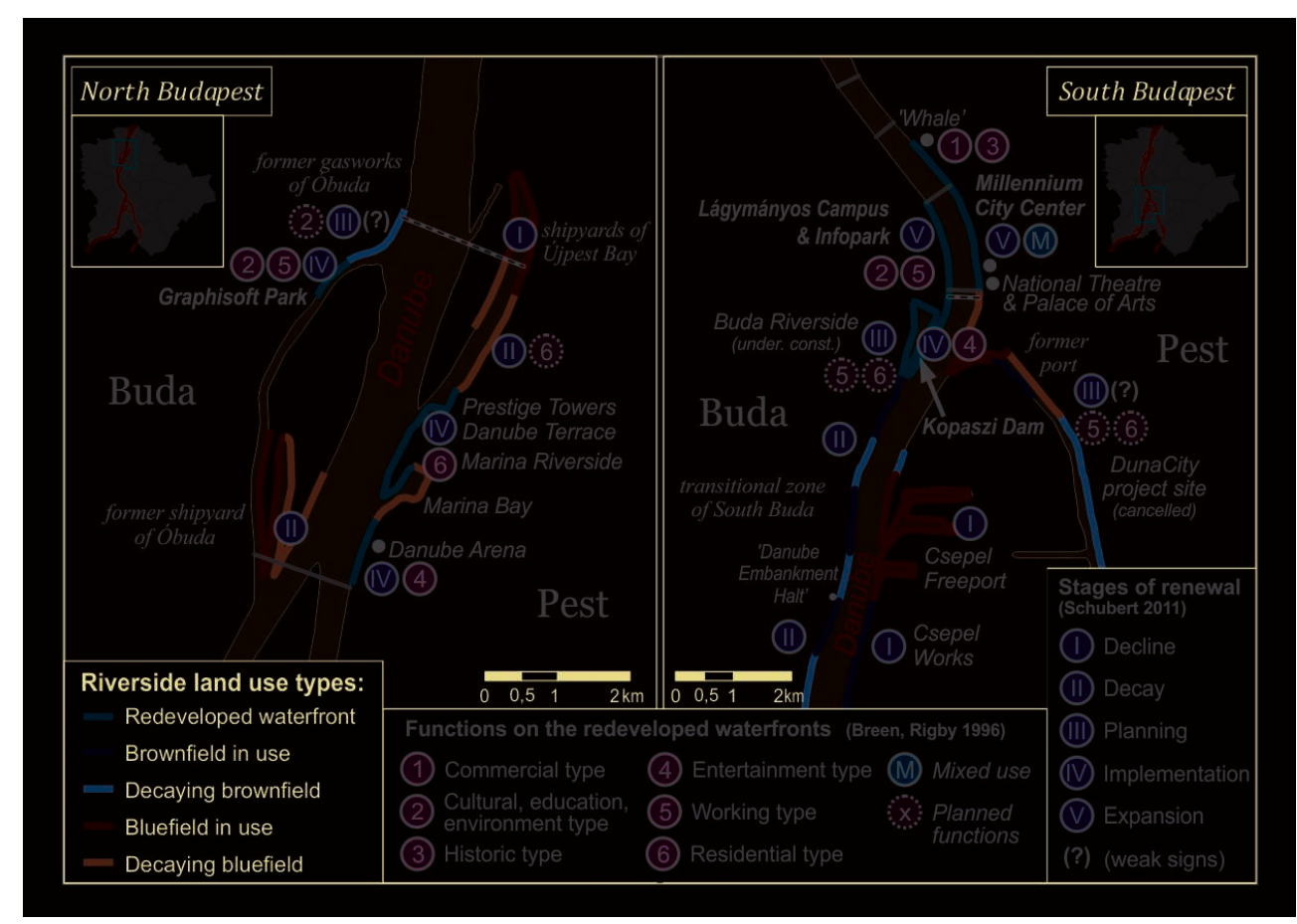

SOURCE: THE AUTHOR'S OWN WORK BASED ON AERIAL PHOTOS, GOOgLE EARTH IMAgES AND DETAILED fIELD SURVEY

Concerning Budapest (Figure 1), both the Northern and Southern riverside brownfield zones have industrial elements that are still active. In addition to the current port function of Csepel Freeport (the most important international port of Hungary), the logistic functions of the riverside parts of the adjacent Csepel Works (formerly the largest industrial complex of Hungary), or the repairing activities of the shipyards of North Pest (Ujjpest Bay), there are also extensive less used sites. By and large, original functions are declining.

11 Some of the neighbouring areas, i.e. other former shipyards of North Buda and North Pest, are currently in the second phase; these are decaying zones. Large parts of their original infrastructure have already been demolished. Therefore, these are potential renewable bluefields. The situation of the underutilized sites of the transitional zone of South Buda is worse (except for the surroundings of Kopaszi Dam, see below), since these have no real connection to the Danube, so that their 'waterfront regeneration' is not likely to happen in the near future. However, sporadic attempts of renewal can be found, such as in the case of the Danube Embankment Halt (a unique bar on the riverside for cyclists, see Figure 6/A), indicating an emerging claim for available waterfronts among local residents.

12 Buda Riverside (BudaPart) is exactly at the end of the third stage because it has recently left the state of being just a plan; the realization of the first phase of a future residential and office area is in progress (Figure 2). The first apartments are planned to be completed in 2018. Apart from this project, other concepts have only remained plans yet. Dunacity would have been a similarly large-scale office and residential neighbourhood in South Pest (close to the most important side-branch of Danube) but the 2008 financial crisis prevented the execution of the project. No construction works were taking place at the site, it has only been cleansed from the vast majority of 
original infrastructural objects. The Gasworks of óbuda (Northern part of the Buda side) is another example; here, even though design competitions have been organized several times, no real preparations can be found on the site to dare. Consequently, it is closer to reality if the latter two are considered to be stucked between the second and the third stages.

Figure 2. Buda Riverside: a site where the realization of plans has recently started.
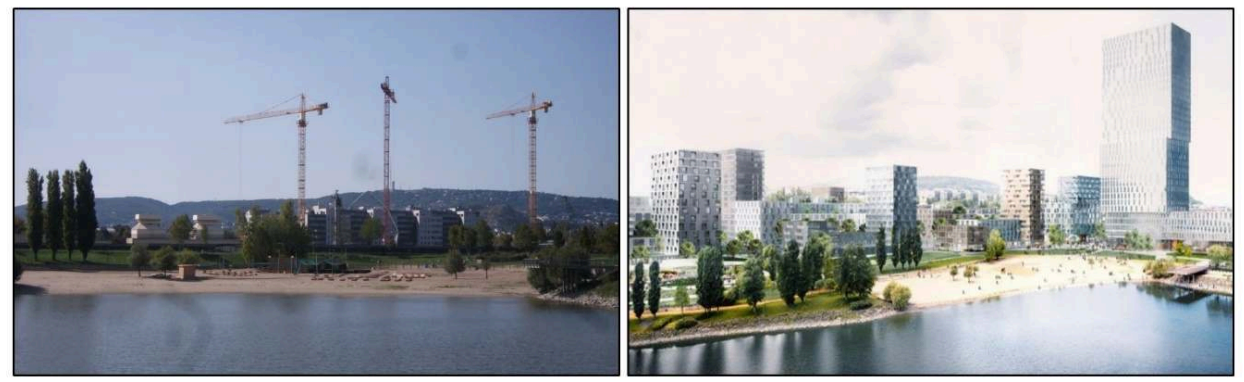

Figure 2/A: Cranes on the building site.

Figure 2/B: Visual design from the webpage of the investor.

Source: 2/A - own photo; 2/B - www.budapart.hu

The sites of the fourth stage are the ones where redevelopment is still in process. Graphisoft Park (an R\&D park on the riverfront of North Buda, close to the abovementioned former gasworks) and the ensemble of Marina Riverside (Marina Part), Danube Terrace and Prestige Towers, a newly-built upper-class residential area in North Pest (Figure 3/A) belong to this group. None of them is a gated site literally but they surely satisfy the demands of an absolutely narrow class of society. The clearest example is Marina Bay, a nearby yacht harbor transformed from a former berthing bay of dredgeships. On the one hand, it is a well recognizable type of bluefield regeneration but on the other hand, it caters to the demands of a small group of wealthy people. Indeed, the investors have not taken into consideration the local social context: the surrounding area has been a traditional workers' quarter. Even though the whole district is under significant urban transformation, this waterfront neighbourhood is still in striking contrast to its immediate surroundings. Danube Arena, the riverside venue of the FINA 2017 World Championship, is also relatively close to Marina Riverside. It might be called a renewed waterfront as well, but in fact, it has no strong connection with the functional changes of its neighbourhood, nor with the riverbanks. 
Figure 3. Regenerated waterfronts - different degrees of indirect exclusion?
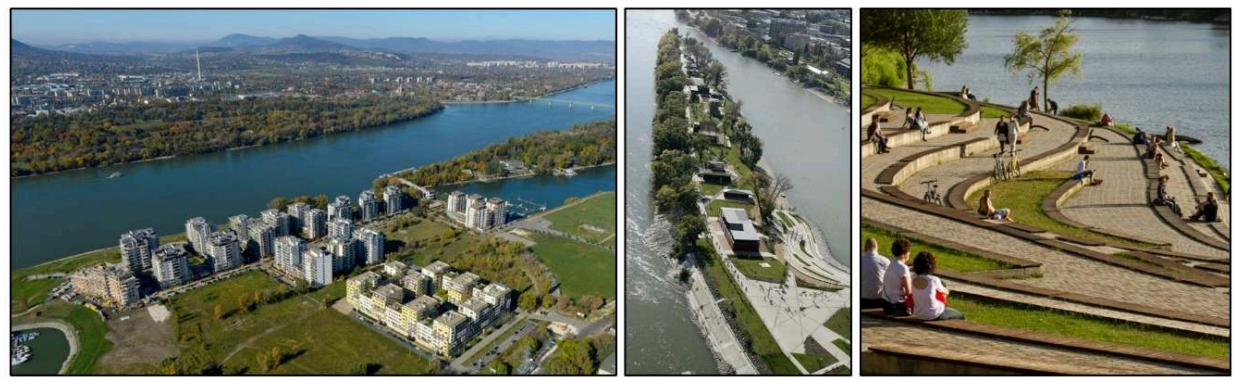

Figure 3/A: Upper-class residential complex in North Pest: Marina Riverside and surroundings.

Figure 3/B: Bars and restaurants along Kopaszi-Dam.

Figure 3/C: Sunbathing terrace on the same site.

Source: 3/A - dunaterasz.hu; 3/B - www.pinterest.com; 3/C - https://welovebudapest.com/

Kopaszi Dam, originally an important artifact of river regulation in South Buda, has become one of the rare examples of real bluefield regeneration in Budapest. This site had been used for watersports and hobby fishing, but during the transition from socialism to capitalism it became an illegal dumping ground. Then from 2007 onwards, it was turned into a public park, numerous restaurants and bars were opened, and nowadays it is one of the most popular recreational sites (Figure 3/B-C), where at least the water-body is touchable and a few piers for rowboats are available. There is no restriction on entrance depending on social status but the high prices definitely filter the people consuming in the bars, and the police station at the entrance also has a role in controlling. Therefore, Kopaszi Dam is an example of the transformation of an unregulated, publicly owned area into a privatized, controlled consumer space.

The site of Millennium City Center is a special example of the heritage of socialist land use: it was originally an underused, space consuming marshalling yard on one of the most valuable riverside plots, in the vicinity of the inner-city (Berki, 2012). The railway tracks were cleared up as part of the preparations for the above-mentioned Expo'95. Later, two important buildings for cultural purposes were built here: the National Theatre (opened in 2002, surrounded by harsh political debates), and the Palace of Arts (in 2005). In addition to these, several office buildings were constructed along the riverfront. Owing to the weak national regulatory system, the local government had little chance to efficiently influence the final results of construction works. (The lack of efficient, well-organized and consistent waterfront regulation is not Budapest's special problem, the situation in other post-socialist cities is considered as even worse [see Cybriwsky, 2016; Gonçalves et al., 2016]). The interests of the private investor - who acquired the majority of the site - undoubtedly dictated the formation of the entire neighbourhood. Although the architectural quality of the buildings is subject to constant debates, Bodnár and Veres (2013) argue that the development of the site exceeds itself, 'showing the contours of a more systematic waterfront regeneration process' (ibid., p. 103). Accepting this opinion, we might state that Millennium City Center has already reached the fifth stage of Schubert's (2011) model. The redevelopment process has already affected the closest parts of the neighbouring (predominantly industrial) zone: new residential buildings have been erected and former steam mills have been converted into offices etc. 
Figure 4. Riverside renewal on the scale of a neighbourhood.
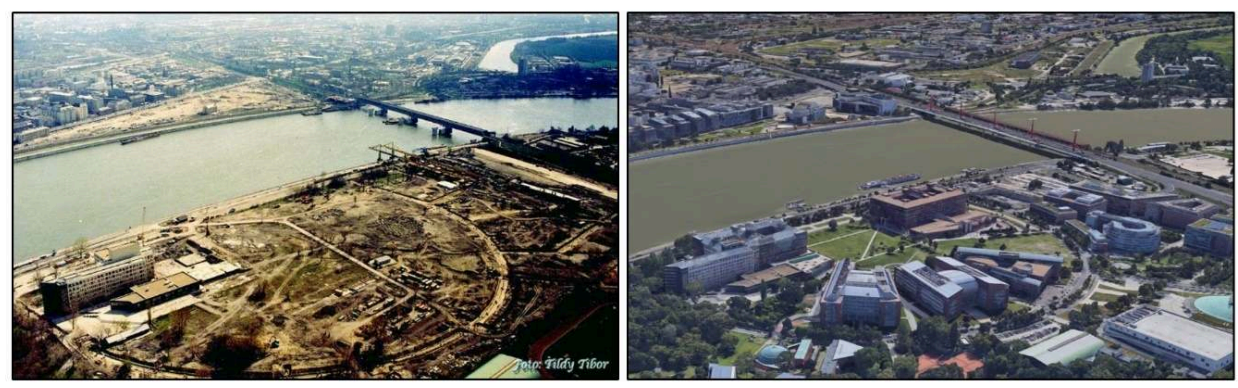

Figure 4/A: The sites cleansed for the construction works of Expo '95 Vienna-Budapest.

Figure 4/B: Lágymányos Campus and Infopark in the foreground, Millennium City Center on the opposite site.

SOURCE: 4/A - PHOTO BY TILDY, T.; 4/B - GOOgLE EARTH IMAgE OF THE SITE

Lágymányos Campus (of Eötvös Loránd University and of the Budapest University of Technology and Economics) and Infopark (a newly built office-campus) might also be regarded as a riverside site of neighbourhood-scale urban renewal (Figure 4). This zone is located on the opposite side of Danube, and it would have formed the main venue of Expo'95, together with Millennium City Center. The expansion of R\&D and office-services functions is continuous here; the construction of a research center on the riverbank has just been finished. Unfortunately, the buildings in this neighbourhood do not have any direct connection to 'waterspace' either, as two highways (one on the upper and one on the lower embankment) physically separate them.

Regarding the phases of renewal, we might conclude that the riverfronts of Budapest are highly heterogenous, with several transformation processes still going on.

\section{New functions on urban waterfronts and their appearance in Budapest}

In addition to the steps of redevelopment, the purposes of regeneration and the newly obtained functions might also be classified. An early example of this categorization is that of Mann's (1988) study, in which the types are distinguished according to the main aim of the renewal ${ }^{6}$. Since the waterfronts of Budapest showcase a highly fragmented pattern (not just in their stages of transformation but also according to the motivations of their redevelopment), several of these categories may be recognized ${ }^{7}$.

Types of regeneration that can possibly contribute to the satisfaction of the 'demand for open edges' are essential in recent waterfront renewal. As for Budapest, the entire cityscape is essentially connected to the Danube, so that both local residents and tourists claim pedestrian zones alongside the river. However, there are just a few shorter sections of the (upper) embankments in the inner-city where one can walk and take photos. As these parts are not real promenades, and they are mainly used by tourists, the voice of local residents has become stronger, and several bottom-up initiatives have appeared over the last years ${ }^{8}$. Still, these activities concentrate on the inner-city where highways on the lower embankments separate the city from the water. Without denying the importance of these movements, it should not be forgotten that the respective riversides only add up to less than $20 \%$ of the total length of 
Danube's banks within the administrative boundaries of Budapest. What is more, the riversides located in the transitional zones of previously developed lands are often underused, thus they can be regarded as potential areas for ensuring easy access to the water's edge. The needs of local residents have become (only partially) noticed by the planners: Kopaszi Dam, for example, satisfies this demand. On the whole, however, 'greenness' and 'openness' form only smaller (obligatory?) parts of the overwhelming majority of projects. The main aim is to enter environmental amenities in the service of the real-estate market, like in the case of the already existing Marina Riverside, the currently constructed Buda Riverside and the never realized DunaCity project. (It is more or less comparable to other post-socialist cities that targeted green area developments around luxury condominiums [He, 2007].) If availability to the public were the main goal, vast underused riverside brownfields should have been revitalized and opened, and in parallel, renaturalization (Scherrer, 2004) should have also been reinforced on larger-scale. Such initiatives would definitely enhance liveability. In addition to liveability, uniqueness cannot be overlooked either. After the cancellation of Expo'95/'96, the aim was to carry out a smaller scale development on a limited part of the original site, creating something similar to what Mann (1988) called a 'people place' (a site that is popular and regularly visited because of its own characteristics). The specifities of 'environmental art' type can also be observed here, as around the new National Theater and the Palace of Arts, some of the edifices (a zikkurat and the imitated facade of the former National Theater in a pond) attempt to create an extraordinary milieu (Figure 5/A), and the panorama of the Danube and the inner-city is 'used' as the background of a symbolic ship's prow. Nevertheless, due to financial limits and weak public control, the overall character of the site became predominantly commercial (as described above). The change in the offical name of the site is also vividly descriptive: originally it was called Millennium Cultural Center, but nowadays it is officially called Millennium City Center.

Figure 5. Newly built and revitalized historic buildings as 'iconic edifices' of Budapest's waterfront.
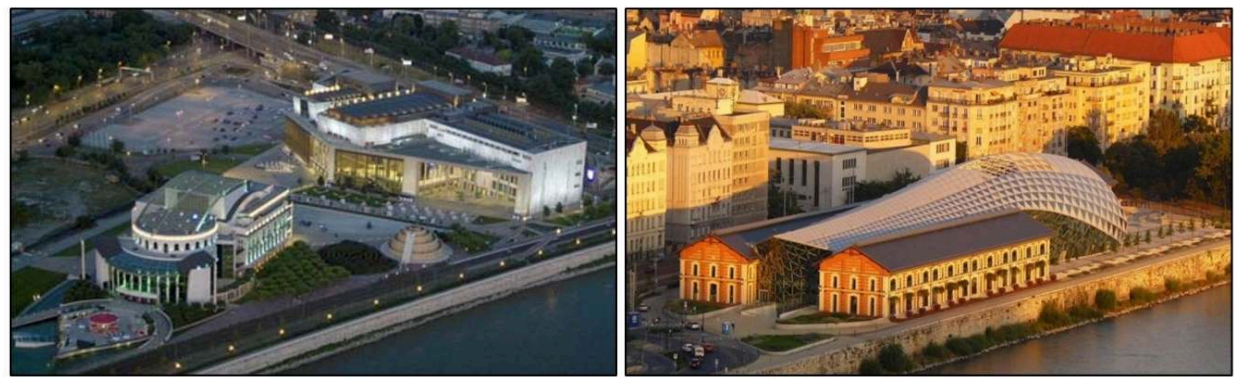

Figure 5/A: The National Theater and the Palace of Arts in Millennium City Center.

Figure 5/B: The 'Whale', a partially successful/failed rehabilitation of former public warehouses.

Source: 5/A - www.civertan.hu; 5/B - www.pinterest.com

21 A particular type of waterfront regeneration is called 'Festival marketplace'. The archetype of it is a new urban retail landscape created from historic port surroundings, using the narrative of bringing back the atmosphere of bygone days (Goss, 1996). This notion was originally used in coastal US cities where ports have been transformed following the rehabiliation schema of the very same urban development corporation but later on, the possibilities of exporting these practices to Europe was also examined 
(Gravari-Barbas, 1998). Both above-mentioned studies agree that these 'dream-houses of contemporary commodity consumption' (Goss, 1996, p. 241.) only work well in the US context (even there, the copies of the original ones are less successful). Budapest's ' Whale might be considered as a festival marketplace in a broader sense. This conspicuous building stands on the Pest side, between Millenium City Center and the very center of the inner-city. It was planned to be a key site of 'Budapest, European Capital of Culture 2010'. Although Budapest did not win the competition for this event, the city has not rejected to build this iconic edifice, transformed from public warehouses on the Danube's embankment (Figure 5/B). The original, spontaneous function - an alternative pub, partially utilizing the ruiny buildings - was removed when preparation works of the project started. The story of the execution itself is rather intriguing. The invitation of a 'starchitect' (Dutch architect Kas Oosterhuis) is nearly a direct copy of Western practices, and the choice of name ('CET - Central European Time') ${ }^{9}$ was also ambitious. Then a somewhat typical 'post-socialist twist' happened: due to quarrels between the local government and the planner, the project was stalled, and eventually the building was realized without the original architect in a significantly cheaper but definitely less decorative way, having a less ingenious name ${ }^{10}$. Even though the building itself is not obviously off-context, like other edifices planned to be 'iconic' in postsocialist cities (Gonçalves et al., 2016), the political skirmish and the constant delays of construction works eroded the success of the project. What is more, the originally planned cultural functions were gradually overtaken by commercial functions, as a result of which the 'Whale' has become not much more than a riverside shopping mall for the upper class, wrapped in an artifically historical decoration. The mall has not become really popular, several empty shops might be found inside (thus the similarity to Bordeaux's Quai des Marques, with its vacant stores in former warehouses [Gasnier, 2013] is quite striking) but the bar-terraces with a magnificent view to the Danube are getting more and more frequently visited, creating an animated space of consumption (Figure 6/B), being common for festival marketplaces. In Budapest, broadly speaking, there are more and more signs of the expansion of controlled and aestheticized urban landscapes (what Gravari-Barbas [2000] calls 'festival city'), but the 'Whale' is the only real waterfront site among these.

Figure 6. Contrast of spontaneous and 'festival marketplace' type functional change on the waterfront.
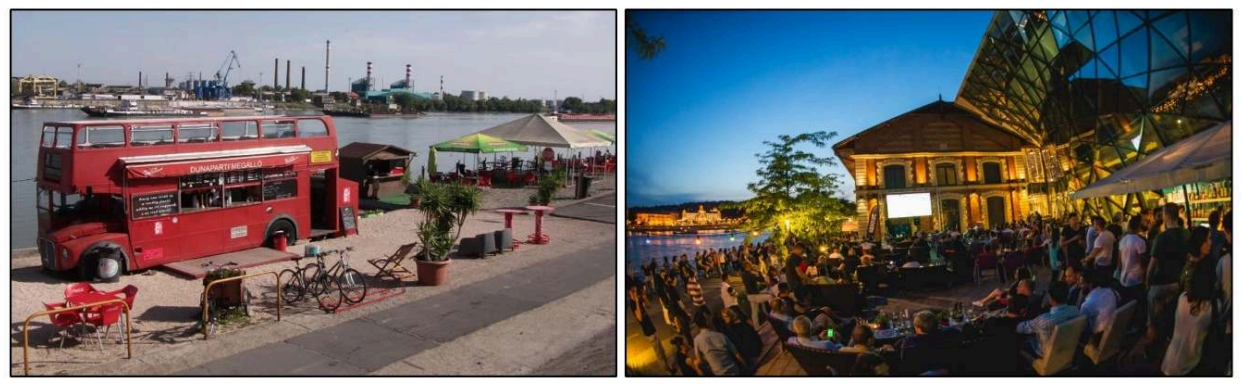

FIgURE 6/A: 'DANUBE EMBANKMENT HALT' BICYCLIST BUFFET IN SOUTH BUDA WITH A VIEW ON FORMER CSEPEL WORKS.

FIgURE 6/B: THE TERRACE OF THE 'WHALE' ON A SUMMER EVENINg: AN ANIMATED SPACE OF CONSUMPTION.

Source: 6/A - own photo; 6/B - www.tripadvisor.co.hu 
Breen and Rigby's (1996) categorization of the new functions of waterfronts concentrates on less spectacular but definitely more permanent everyday uses. They distinguish between (1) 'commercial type', (2) 'cultural, education, environment type', (3) ' historic type', (4) 'entertainment type', (5) 'working type', and (6) 'residential type' waterfronts. In the case of Budapest (Figure 1), Marina Riverside is a good example of monofunctional 'residential type', Kopaszi Dam similarly well exemplifies 'entertainment type'. Additionally, 'working type' is mixed with 'educational type' in the case of Graphisoft Park, as well as in Lágymányos Campus and Infopark, while 'commercial type' and 'entertainment type' is hybridized in the case of 'Whale'. As a waterfront site proceeds in the course of regeneration, it is somewhat natural (and also desired) to become a 'mixed use' one. Millenium City Center was originally (ought to be) a 'cultural type' but in the end, it rather turned out to be a 'working type' or a 'commercial type' (and also 'residential type' to a lesser extent). Therefore, the categories of Breen and Rigby (1996) might rather be linked to the $3^{\text {rd }}$ and $4^{\text {th }}$ stages of the model of Schubert (2011). If a waterfront enters into the $5^{\text {th }}$ phase, it obviously includes a diversification of local functions. Developers should even promote mixed land use, as monofunctional neighbourhoods are rather unfavorable.

Either special aims of regeneration or everyday functions are taken into consideration, the apparent diversity of the urban waterfronts of Budapest is eye-catching.

\section{Conclusions}

Real 'waterfront regeneration', i.e. the renewal and functional transformation of previously developed riverside sites (for satisfying the needs of creative and upper class residents) only sporadically appears in Budapest. Moreover, most of the potential venues have definite weaknesses. Many of these are caused by general post-socialist circumstances (including weak regulations, hasty privatization, the dominance of private capital, or the lack of control by local governments) but local conditions also influence the results of regeneration processes. As examples of these, newly built riverside R\&D and office campuses do not have any connection with the riverbank, and riverside residential areas do not have their unique atmosphere that could contribute to the image of Budapest as a city on the Danube. The only sites that can indeed be called as 'waterfronts' (in alignment with the related literature) are Kopaszi Dam and Millennium City Center. The recreational facilities of the previous and the iconic buildings of the latter (together with the 'Whale') have become well recognizable elements of Budapest's Danube banks, step-by-step forming a 'fluvial facade' (Romain, 2010) outside the city-center. Nevertheless, even these sites cannot be regarded as 'bluefields', as functions connected to waterspace are missing here as well, and the Danube is nothing more than a scenery.

Consequently, calling Budapest a waterfront-city seems to be an exaggeration. However, the process of renewal has visibly intensified, and the emerging boom of the real estate market will probably further reshape the riversides of Budapest's transitional zones (previously developed lands). The application of international models has shown that even under post-socialist circumstances the process is comparable to Western cities. Nevertheless, post-socialist cities are more than simple empirical testing grounds of Western concepts and theories. As Robinson (2016) considers, in search of interlinkages and common points in a globalizing urban theory, 
differences arising from the diverse contexts should also be emphasized. The own logic of functioning of post-socialist cities might also be recognized on their waterfronts. While a large part of post-socialist urban studies investigates housing estates and industrial sites constructed during the socialist era, waterfronts - as already intensively used zones during the previous period - provide examples of the transformation of (mainly or partly) pre-socialist structures under post-socialist circumstances. It might be observed predominantly in cities with longer histories, and the capital cities traversed by large rivers are by far the most examined among them. Based on a broad array of previous works, these cities have already suffered from several types of wrong-headed regeneration ideas. 'Urban uncertainity', i.e. the unpredictability of the realization of large-scale plans is an obstacle of regeneration on the banks of River Sava in Belgrade (Arandelovic et al., 2017). As the opposite extreme, large-scale 'state-sponsored gentrification' has distorted the urban structures in the case of Shanghai's Suzhou Creek. This gigaproject was over-supported by the public administration in a socially blind manner, as it induced the relocation of thousands of lower class people (He, 2007). Less strikingly, 'small-scale \& hidden gentrification' is taking place along the banks of River Dnipro in Kyiv. Private actors occupy the riverfront of the city without compensating the public for loosing green spaces (Cybriwsky, 2016). A rather similar process can be noticed on the Danube riversides in Bratislava, what is called an 'uneven struggle for bluefields' by Machala (2014). Tbilisi has also witnessed riverfront regeneration on River Kura with keeping some of its public gardens, but the newly built edifices designed by Western architects are over-scaled and off-the-context of the surrounding historical districts (Gonçalves et al., 2016). Budapest has also fallen in some of the pitfalls of copying Western examples (e.g. the failure of Expo'95, the over-scaled and bankrupt DunaCity project, the cooperation with a Western 'starchitect' ending in a scandal in the case of CET, or the long-lasting political and architectural debates around the new National Theater, originally designated to be an 'iconic' waterfront edifice). These obvious mistakes, added to the above-mentioned ones, shall be lessons for other Center and Eastern European (and other semi-peripherical) cities facing waterfront regeneration. On the other hand, however, as the economic transition and the changes of the regulatory system were not as hasty as in the cities of the former Soviet Union or the cities of the People's Republic of China, the signs of a 'typical' post-socialist metamorphosis (often charged with negative connotation) are not so strong in the Hungarian capital. In addition to the already completed or ongoing projects, Budapest still has potentially valuable under-utilized riverfront zones. Learning from our own mistakes and from those of other post-socialist cities could help achieving sustainability, realizing more contextualized plans, rationalizing the use of financial resources and promoting community interests, similarly to $4^{\text {th }}$ generation waterfront cities. At the same time, opening to 'waterspaces' - by supporting waterconnected functions - should not be forgotten either. 


\section{BIBLIOGRAPHY}

ARANDELOVIC B. et al. (2017), "Belgrade: Imaging the future and creating a European metropolis", Cities, 63, pp. 1-19.

BARTA Gy. et al. (2006), "Rehabilitating the brownfield zones of Budapest", Discussion Papers, Pécs, Centre for Regional Studies of Hungarian Academy of Sciences, $75 \mathrm{p}$.

BERKI M. (2012), "Post-socialist transformation of former industrial areas: a case study of Soroksári Road, Budapest”, Metropolitan regions in Europe, Budapest, Austrian-Hungarian Action Fund, pp. 83-99.

BETHEMONT J., PELLETIER J. (1990), “Lyon et ses fleuves: des berges perdues aux quais retrouvés”, Revue de géographie de Lyon, 65, 4, pp. 300-307.

BODNÁR J., VERES J. (2013), “The petty politics of a megaproject in Budapest”, A Worldwide View Research in Urban Sociology, 13, pp. 83-106.

BREEN A., RIGBY D. (1996), The new waterfront - A worldwide urban success story, Singapore, McGraw-Hill, $224 \mathrm{p}$.

BROWNILL S. (2011), "London Docklands Revisited: The Dynamics of Waterfront Development", in DESFOR G. et al. (eds.), Transforming Urban Waterfronts - Fixity and Flow, New York, Routledge, pp. 121-142.

BRUTTOMESSO R. (ed.) (1993), Waterfronts: A New Frontier for Cities on Water, Venice, International Centre Cities on Water, $351 \mathrm{p}$.

CARTA M., RONSIVALLE D. (eds.) (2016), The Fluid City Paradigm: Waterfront Regeneration as an Urban Renewal Strategy, Springer-Università Degli Studi di Palermo. 163 p.

CHARLIER J. (1992), “The regeneration of old port areas for new port uses”, in HOYLE B.S., PINDER D. (eds.), European Port Cities in Transition, London, Belhaven Press, pp. 137-153.

COOK A. et al. (2001), "Port and city relations: San Francisco and Boston", in MARSHALL R. (ed.), Waterfronts in Post-industrial cities, London, New York, Spon, pp. 117-133.

CYBRIWSKY R.A. (2016), “Whose city? Kyiv and its river after socialism”, Geografiska Annaler Series B, Human Geography, 98, 4, pp. 367-379.

DAVIDSON M. (2009), “Waterfront Development”, in CASTREE N. et al. (eds.), International Encyclopedia of Human Geography, Elsevier, pp. 215-221.

DESFOR G. et al. (eds.) (2011), Transforming Urban Waterfronts - Fixity and Flow, New York, Routledge, $320 \mathrm{p}$.

GASNIER A. (2013), "La fonction commerciale dans les politiques de renouvellement des fronts d'eau urbains à Bordeaux et Saint-Nazaire: une résilience limitée?", Annales de la Recherche Urbaine, 108, pp. 82-95.

GONÇALVES J. et al. (2016), “The Riverfront as a Mirror: The Case of the Transformations in PostSoviet Cities", New Water Policy and Practice, 2, 2, pp. 21-35.

GOSS J. (1996), "Disquiet on the waterfront: reflections on nostalgia and utopia in the urban archetypes of festival marketplaces", Urban Geography, 17, 3, pp. 221-247. 
GRAVARI-BARBAS M. (1998), “La «festival market place» ou le tourisme sur le front d'eau. Un modèle urbain américain à exporter”, Norois, Villes et tourisme, 178, pp. 261-278.

GRAVARI-BARBAS M. (2000), "Stratégies de requalification dans la ville contemporaine. L'esthétisation du paysage urbain, symptôme d'une privatisation croissante des espaces publics", Cahiers de la Méditerranée, 60, 1, pp. 223-247.

HE S. (2007), "State-sponsored Gentrification Under Market Transition The Case of Shanghai", Urban Affairs Review, 43, 2, pp. 171-198.

HOYLE B.S. (1988), "Development dynamics at the port-city interface”, in HOYLE B.S. et al. (eds.), Revitalising the Waterfront: International Dimensions of Dockland Redevelopment, London, Belhaven, pp. 3-19.

HOYLE B.S. (2000), "Global and local change on the port-city waterfront", Geographical Review, 90, 3, pp. 395-417.

HOYLE B.S. (ed.) (1996), Cityports, Coastal Zones and Regional Change, Chichester, Wiley, 316 p.

HOYLE B.S. et al. (eds.) (1988), Revitalising the Waterfront: International Dimensions of Docklands Development, London, Belhaven, $265 \mathrm{p}$.

IZSÁK É., PROBÁLD F. (2008), “Klimatikus környezet és városfejlesztés Budapesten” (“Climatic environment and urban development in Budapest”), in OROSZ Z., FAZEKAS I. (eds.), Települési környezet (Settlement environment), Debrecen, DE Kossuth Egyetemi Kiadó, pp. 116-121.

MACHALA B. (2014), “The uneven struggle for bluefields: transformation in post-socialist Bratislava”, Hungarian Geographical Bulletin, 63, 3, pp. 335-352.

MALONE P. (ed.) (1996), City, Capital and Water, London, Routledge, 288 p.

MANN R.B. (1988), “Ten trends in the continuing renaissance of urban waterfronts", Landscape and Urban Planning, 16, pp. 177-199.

MARSHALL R. (ed.) (2001), Waterfronts in Post-industrial cities, London-New York, Spon, 194 p.

MOUNTJOY A. (2013) “Lessons from China's Waterfronts”, Planning, 7, pp. 44-46.

PELLETIER J. (1990), “Sur les relations de la ville et des cours d'eau”, Revue de géographie de Lyon, 65,4 , pp. 233-239.

PINCH P., MUNT I. (2002), “Blue Belts: An Agenda for “Waterspace' planning in the UK”, Planning Practice and Research, 17, 2, pp. 159-174.

ROBINSON J. (2016), "Starting from anywhere, making connections: globalizing urban theory", Eurasian Geography and Economics, 57, 4-5, pp. 643-657.

ROMAIN F. (2010), “Le fleuve, porteur d'images urbaines: formes et enjeux”, Géocarrefour, 85, 3, pp. 253-260.

SCHERRER F. (2004), "L'eau urbaine ou le pouvoir de renaturer", Cybergeo: European Journal of Geography, http://journals.openedition.org/cybergeo/1496, consulted: 31.01.2018.

SCHUBERT D. (2011), "Waterfront Revitalizations: From a Local to a Regional Perspective in London, Barcelona, Rotterdam, and Hamburg”, in DESFOR G. et al. (eds.), Transforming Urban Waterfronts - Fixity and Flow, New York, Routledge, pp. 74-97.

SHAW B. (2001), "History at the water's edge", in MARSHALL R. (ed.), Waterfronts in Post-industrial cities, London-New York, Spon, pp. 160-172. 
SMITH H., FERRARI M.S.G. (eds.) (2012), Waterfront Regeneration: Experiences in City-Building, London-New York, Routledge, 236 p.

SZABÓ P., GORDOS T. (2015), "The effects of changing possibilities of urban development on the waterfront development in Budapest”, Studia Regionalia, 41-42, pp. 129-140.

VEGARA A. (2001), "New Millennium Bilbao", in MARSHALL R. (ed.), Waterfronts in Post-industrial cities London-New York, Spon, pp. 86-94.

\section{NOTES}

1. Francophone literature has already paid attention to city-river relations since the 1990s (e.g. Bethemont and Pelletier, 1990; Pelletier, 1990 etc.), and more recent studies discuss urban riversides as means of either bringing back nature to the urban environment (Scherrer, 2004), or redirecting the city to a natural axis (Romain, 2010). In the British context, 'canal-based redevelopment' has become popular (Hoyle, 2000). Rapidly urbanizing countries have also turned the attention to their riverfronts (e.g. He, 2007; Mountjoy 2013 etc.), even though the riverfront sites appearing in these studies are located close to estuaries. In the case of Central and Eastern European post-socialist cities, where - in many cases - the sea is far away, riverfront development is also quite apparent (e.g. Machala, 2014; Cybriwsky, 2016; Gonçalves et al., 2016).

2. Based on the analysis of archival aerial photographs (from the 1970s and from 2000), along with Google Earth images (June 2015), the length of the riverbanks of the Danube's main branch is $58 \mathrm{~km}$. If we also take other branches, islands and bays into consideration, the total length of riverbanks exceeds $122 \mathrm{~km}$. About $18 \mathrm{~km}$ of the main riverbanks can be found in previously used (industrial) zones. If sidebanks are also taken into account, about $33 \mathrm{~km}$ can be categorized as brownfields (Izsák and Probáld [2008] had approximately the same results.)

3. For example the port-city interlinkages model (Hoyle, 1988) and the waterfront development lifecycle model (Charlier, 1992).

4. Or a 'zone of cooperation'in an ideal case, as mentioned by the author.

5. They argue that 'infrastructures, such as piers, wharfs, jetties, slipways and boatyards, need to be acknowledged as inextricably related to the use and 'development' of waterspaces. Such sites, for instance, could be reclassified as 'bluefield' sites and be required to conform to river-dependent and river-enhancing uses' (Pinch and Munt, 2002, p. 172). Thus, the concept is not limited to large seaside port-towns; inland riverside cities are also involved in it.

6. In Mann's (1988) typology, the purposes of reuse go beyond simple commercial and residential uses. Many of them are based on community demands and environmental considerations (such as the 'demand for open edges', 'taming the highway' and smaller scale 'banksides' type revitalization), or on land-art and touristic thematics (for instance 'historic restoration', 'people/ market places', 'world exposition', 'environmental art' and 'festivals/ephemeral art' types).

7. Since Mann (1988) described different types on the example of different cities, it is obvious that all these categories cannot be found in the same city. However, in the case of cities with vast waterfront/riverfront zones, like Budapest, more than one type of regeneration might occur.

8. The most active NGO is Valyo (VÁros \& foLYÓ, literally 'City \& River'), which organizes a great number of community events on the embankments, bridges etc.

9. 'Cet' is a synonym of whale in Hungarian. This refers to the shape of the new building, but at the same time 'Central European Time' also suggests that Budapest gives the rhythm to the region.

10. 'Bálna', another Hungarian word for whale, only refers to the shape of the building. 


\section{ABSTRACTS}

Although waterfront regeneration has stood in the forefront of the urban development of economically developed countries for several decades, and global peripheries have also (re)discovered their reusable waterfronts since the turn of the millennia, post-socialist urban geography has turned to this topic only recently. The remarkable length of the Danube riverside in Budapest also lends itself for a case study. Therefore, in order to fill this research gap, this paper aims to place the transformation of Budapest's riverfront brownfields in the broader context of international trends. It examines local processes vis-à-vis the global diffusion of waterfront regeneration, with particular emphasis on the generations of waterfronts. Subsequently, it applies the cyclic model of dereliction and revitalization on the example of Budapest, along with a functional categorization. In addition to these, the concept of 'bluefields' is brought into the discussion as well. Since the renewal of Budapest's riverfronts is rather heterogenous, the paper also intends to refine the overall picture of their transformation by providing a concise description of various pieces of this mosaic. In doing so, post-socialist circumstances and local specificities are taken into consideration simultaneously.

La régénération du front d'eau ('waterfront') est apparue il y a plusieurs décennies dans les pays développés. Plus récemment, au cours des années 2000, les pays les moins avancés ont également (re)découvert ces zones réutilisables au bord de l'eau. A contrario, la géographie urbaine des villes post-socialistes ne s'ouvre que depuis peu à cette thématique. La longueur remarquable des rives du Danube à Budapest offre une étude de cas significative. Le but de cet article consiste donc à examiner dans quelle mesure la transformation des friches industrielles des rives de la capitale hongroise s'adapte aux tendances internationales au sens large. Le processus local est alors comparé à la diffusion générale de régénération du front d'eau, avec un accent particulier sur les différentes générations de renouvellement. Par la suite, le modèle cyclique de délaissement et de revitalisation est appliqué à l'exemple de Budapest accompagné d'une catégorisation fonctionnelle. En plus de ceux-ci, le concept de 'champs bleus' ('bluefield') est également introduit au questionnement. Étant donné que la régénération des rives de Budapest est assez hétérogène, cet article a donc pour but d'affiner l'image d'ensemble en donnant une description concise des différentes pièces de cette mosaïque. Pour ce faire, les circonstances postsocialistes et les spécificités locales sont simultanément prises en compte.

\section{INDEX}

Mots-clés: Budapest, ville post-socialiste, front d'eau urbain/front fluvial

Keywords: Budapest, post-socialist city, waterfront/riverfront

\section{AUTHOR}

\section{GABOR TOLNAI}

ELTE Eötvös Loránd University, Budapest, Hungary, Department of Social and Economic Geography, http://orcid.org/0000-0001-9055-3431, gntolnai@caesar.elte.hu 